\title{
KEHIDUPAN BURUH TANI PEREMPUAN DALAM MEMBANTU PEREKONOMIAN RUMAH TANGGA
}

\author{
Cut Intan ${ }^{1}$, Richa Meliza ${ }^{2}$ \\ 1,2 Program Studi Antropologi, Universitas Malikussaleh Lhokseumawe \\ Aceh-Indonesia
}

Korespondensi: cutintan.net2018@gmail.com

\begin{abstract}
Abstrak: Penelitian ini bertema antropologi ekonomi yang mengkaji tentang kehidupan buruh tani perempuan dalam membantu perekonomian keluarga di Gampong Keude Krueng, Kecamatan Kuta Makmur, Kabupaten Aceh Utara. Tujuan dari penelitian ini adalah mendapatkan gambaran serta informasi yang mendalam tentang kehidupan buruh tani perempuan di Gampong Keude Krueng. Penelitian ini menggunakan metode pendekatan fungsional-struktural. Adapun hasil dari penelitian menjelaskan bahwa banyaknya kaum perempuan yang berada di Gampong Keude Krueng memutuskan untuk bekerja sebagai buruh tani dikarenakan tiga faktor utama yaitu: Pertama, faktor ekonomi, dimana penghasilan suami yang tidak mencukupi kebutuhan keluarga. Kedua, faktor pendidikan, dimana rendahnya tingkat pendidikan yang menyebabkan mereka tidak mempunyai keahlian lain. Ketiga, faktor sosial budaya. Keadaan inilah yang menyebabkan para perempuan di Gampong Keude Krueng terjun langsung untuk bekerja di luar rumah guna mendapatkan upah. Para perempuan di Gampong Keude Krueng menjalankan kedua perannya dengan baik tanpa mengesampingkan salah satu perannya baik peran di ranah publik maupun ranah domestik.
\end{abstract}

Kata Kunci: Peran Perempuan, Buruh Tani, Perekonomian. 


\section{A. Pendahuluan}

Sektor pertanian di Indonesia termasuk sektor utama dalam kegiatan ekonomi Indonesia karena sektor pertanian berperan penting dalam penyerapan tenaga kerja, sumber pendapatan masyarakat, perolehan devisa melalui ekspor, penyedia bahan baku bagi industri, serta penanggulangan kemiskinan (Novia, 2015:17). Partisipasi wanita dalam dunia kerja telah memberikan kontribusi yang besar dalam kesejahteraan keluarganya, khususnya bidang ekonomi. Angka wanita pekerja di Indonesia dan juga di Negara lain masih terus meningkat, hal ini dikarenakan adanya beberapa faktor, seperti meningkatnya kesempatan belajar bagi wanita, keberhasilan program keluarga berencana, banyaknya tempat penitipan anak dan kemajuan teknologi yang memungkinkan wanita dapat mengurus masalah keluarga dan masalah pekerjaan sekaligus (Mudzhakad, 2006: 189).

Keadaan demikian membuat para perempuan memiliki dua peran sekaligus, yaitu peran domestik mengurus rumah tangga dan peran publik yang bertugas di luar rumah atau bekerja untuk memenuhi kebutuhan hidup seluruh keluarga. Usaha peran dan sumbangan perempuan dalam pembangunan termasuk menunjang perekonomian keluarga, ternyata wanita Indonesia terutama di pedesaan menyadari sepenuhnya peningkatan taraf hidup dan kemajuan, sehingga terpenuhi kebutuhan spiritual dan materil. Potensi wanita yang cukup besar jumlahnya itu mempunyai arti dan mengambil bagian secara aktif baik dalam pembangunan dan meningkatkan perekonomian keluarga

Keikutsertaan perempuan dalam kegiatan mencari nafkah tidak lain karena pendapatan suami tidak cukup untuk memenuhi kebutuhan hidup keluarganya. Keikutsertaan anggota keluarga dalam kegiatan mencari nafkah merupakan upaya peningkatan pendapatan guna mengatasi masalah memenuhi kebutuhan hidup rumah tangga. Namun demikian perempuan juga diwajibkan melaksanakan kewajibannya sebagai ibu bagi anak-anaknya serta istri bagi suaminya di samping ia juga sebagai wanita pekerja.

Lahan pertanian di Gampong Keude Krueng juga banyak menyerap tenaga kerja dibidang pertanian tidak terkecuali tenaga kerja perempuan. Mata pencaharian masyarakat Gampong Keude Krueng mayoritasnya adalah buruh tani 
sebagai sumber pendapatan utama mereka, Buruh tani bekerja pada jam 07.30 12.00 dan pada jam 01.50-05.50 wib. Para perempuan buruh tani tidak hanya bekerja sebagai buruh tani di desanya saja tetapi perempuan di Gampong Keude Krueng juga bekerja menjadi buruh tani di desa tetangga.

Petani adalah orang yang melakukan kegiatan bercocok tanam hasil bumi atau memelihara hasil ternak dengan tujuan untuk memperoleh kehidupan dari kegiatan yang dilakukannya tersebut. Pada sektor pertanian, petani tidak bisa bekerja secara sendiri dan petani juga membutuhkan buruh tani untuk menyelesaikan pekerjaan mereka. Buruh tani dapat dikatakan sebagai semua orang yang bekerja di ladang milik orang lain dengan tujuan untuk mendapatkan upah. Buruh tani termasuk ke dalam golongan buruh harian lepas (BHL) yang memiliki pengertian buruh yang diikat dengan hubungan kerja dari hari ke hari dan menerima upah sesuai dengan banyaknya hari kerja atau jam kerja atau banyaknya barang atau jenis pekerjaan yang disediakan (Ngangi, 2016: 1-2).

Alasan utama para perempuan di Gampong Keude Krueng bekerja sebagai buruh tani adalah untuk memenuhi kebutuhan hidup serta keinginan tersendiri yang ingin mereka penuhi. Kebutuhan merupakan segala sesuatu yang dibutuhkan manusia dalam kehidupan sehari-harinya. Para perempuan bekerja sebagai buruh tani yaitu karena masalah ekonomi, dimana penghasilan suami yang tidak memadai sehingga membuat mereka terjun langsung untuk bekerja membantu suami guna mendapatkan upah agar bisa memenuhi segala kebutuhan keluarganya, contohnya pemenuhan kebutuhan pangan, kebutuhan sandang, kebutuhan kesehatan, kebutuhan pendidikan anak-anak mereka, serta kebutuhan sosial budayanya.

\section{B. Metode}

Penelitian ini dilakukan di Gampong Keude Krueng, Kecamatan Kuta Makmur, Kabupaten Aceh Utara. Gampong ini merupakan salah satu kawasan pertanian padi di wilayah Kabupaten Aceh Utara. Pertanian merupakan salah satu faktor yang menjadi bagian terpenting bagi masyarakat Kuta Makmur khususnya masyarakat Gampong Keude Krueng. Hingga saat ini mata pencaharian utama mereka masih di sektor pertanian yang membudidayakan padi sebagai sumber pendapatan utama mereka. 
Penelitian ini merupakan penelitian sosial yang menggunakan metode kualitatif dengan fokus kajian Antropologi Ekonomi. Data yang diperoleh dalam penelitian ini adalah data kualitatif sehingga metode analisis yang digunakan merupakan metode analisis kualitatif. Penelitian ini menggunakan penelitian kualitatif dengan maksud untuk memperoleh gambaran yang mendalam dengan menghasilkan data deskriptif tentang masalah yang diamati (Moleong, 2014).

Penelitian ini merupakan suatu penelitian kualitatif dengan jenis penelitian lapangan. Secara umum dalam penelitian kualitatif ini menggunakan dua jenis data, antara lain; (1) Data primer, yaitu data yang diperoleh dari hasil observasi partisipatif (participant observation) dan hasil wawancara (interview) dengan informan di lapangan, (2) Data sekunder, yaitu data yang diperoleh dari dokumen literatur yang memperkaya dari hasil temuan data primer. Adapun data sekunder yang digunakan dalam penelitian ini dari berbagai buku, jurnal, dan data dari informan.

Informan yang menjadi sumber data terkait dengan tema penelitian ini ada dua jenis, antara lain; (1) Informan kunci, yaitu mereka yang mengetahui dan memiliki informasi atau data utama yang diperlukan dalam penelitian. Informan kunci yang dimaksud adalah buruh tani perempuan. (2) Informan penghubung, yaitu masyarakat yang terlibat langsung dalam membantu peneliti atau memberikan informasi dan situasi lokasi penelitian, informan penghubung dalam penelitian ini adalah; bapak Geuchik (kepala Desa), sekdes Gampong dan instansiinstansi pemerintahan lainnya.

\section{Pembahasan}

\section{Peran Ganda Buruh Tani Perempuan}

Peran perempuan dalam rumah tangga merupakan peran penting yang diberikan oleh perempuan sebagai ibu rumah tangga dalam membentuk sebuah keluarga yang sejahtera sebagai unit keluarga terkecil dalam kehidupan masyarakat, berbangsa dan bernegara. Ibu rumah tangga juga merupakan sosok ibu yang berperan dalam: (1). Mengurus rumah tangga seperti memasak, mencuci, menyapu, dan kegiatan domestik lainnya, (2). Mengasuh dan mendidik anakanaknya sebagai satu kelompok dan peranan sosial, (3). Memenuhi kebutuhan efektif dan sosial anak-anaknya, (4). Menjadi anggota masyarakat yang aktif dan 
harmonis dilingkungannya yang diwujudkan dalam berbagai kegiatan seperti PKK, Arisan, Majelis Taklim dan berbagai kegiatan lainnya (Junaidi, 2017 : 2).

Dari penjelasan diatas hal serupa juga terjadi pada masyarakat Gampong Keude Krueng bahwa ibu rumah tangga merupakan para perempuan yang selalu menghabiskan waktunya di rumah, mereka selalu mengerjakan pekerjaan rumahnya seperti memasak untuk keluarganya, menyuci, menyapu, mengurus suami, menjaga dan mendidik anak-anaknya.

Dari hasil wawancara dengan informan menunjukkan bahwa para ibu rumah tangga di Gampong Keude Krueng melakukan perannya dalam kehidupan keluarga dengan baik. Mereka mengurus dan mengelola rumah tangganya dengan baik. Menjalankan perannya sebagai ibu rumah tangga dengan mengurus anak dan suami, mengerjakan pekerjaan rumah, dan juga membantu menambah penghasilan keluarga dengan bekerja sebagai buruh tani setelah semua pekerjaan rumah mereka selesai.

Tuntutan ekonomi dan perubahan anggapan masyarakat bahwa perempuan tidak harus di dapur, telah mendorong perempuan untuk berada pada ranah publik (kerja), baik di pabrik maupun sawah dan ladang (Famelia, 2018: 1).Begitu juga yang terjadi pada masyarakat Gampong Keude Krueng di mana seorang perempuan juga memiliki dua peran sekaligus, mereka harus menjadi seorang ibu rumah tangga dan juga seorang pekerja untuk membantu meringankan beban suaminya. Di samping berperan sebagai ibu rumah tangga, seorang buruh tani harus sebisa mungkin membagi waktu antara seorang ibu dan seorang pekerja. Dalam kesehariannya buruh tani perempuan bekerja mulai pagi bahkan sampai sore agar terpenuhi pendapatan atau kebutuhan keluarga mereka.

\section{Kontribusi Pendapatan Buruh Tani Perempuan}

Upah adalah hak/imbalan yang berupa uang yang diterima oleh seseorang setelah melakukan sebuah pekerjaan. Upah buruh tani perempuan sangat berbeda dengan upah buruh tani laki-laki, hal ini dikarenakan anggapan bahwa laki-laki merupakan pekerja dan pencari nafkah utama dalam keluarga. Dengan bekerjanya istri diluar rumah sebagai buruh tani, maka mereka tentu saja memberikan sumbangan dalam memenuhi kebutuhan ekonomi keluarganya. Dari hasil pendapatannya buruh tani perempuan mengalokasikan penghasilannya untuk : 


\section{Pemenuhan Kebutuhan Ekonomi}

Adapun salah satu motivasi yang mendorong para perempuan untuk bekerja yaitu terutama disebabkan oleh kondisi ekonomi keluarga (Femelia, 2018:2-4). Begitu juga yang terjadi pada masyarakat Gampong Keude Kreung bahwa masalah ekonomi merupakan faktor yang sangat mendorong seseorang untuk bekerja, kurangnya pendapatan suami dan banyaknya kebutuhan terkadang bertolak belakang antara kebutuhan dan pendapatan dalam keluarga, yang terkadang mendorong perempuan (istri) untuk membantu meningkatkan perekonomian keluarga. Setiap hari para buruh tani perempuan mengeluarkan uang belanja kurang lebih sebesar Rp. 20.000, inilah salah satu cara yang bisa dilakukan para buruh tani untuk meminimalisir pengeluaran dengan sikap hemat dalam pemenuhan kebutuhan pangan dapat dilihat dari pola konsumsi dan membiasakan hidup sederhana.

2. Pemenuhan Kebutuhan Pendidikan

Kebutuhan pendidikan merupakan kebutuhan yang tidak bisa ditinggalkan begitu saja oleh buruh tani, pendidikan yang dimaksud adalah pendidikan anak. Ibu adalah wanita pendidik pertama dan utama dalam keluarga bagi anak-anaknya. Semua buruh tani pasti memiliki keinginan agar anaknya memiliki masa depan lebih dari sekedar orang tuanya. Buruh tani mengalokasikan sebagian penghasilannya juga untuk memenuhi kebutuhan pendidikan anaknya. Kebanyakan anak dari buruh tani bersekolah di sekolah SD dan SMP di seputaran kecamatan Kuta Makmur, dan jika sudah SMA biasanya mereka bersekolah ke kota Lhokseumawe namun ada juga yang bersekolah di sekitaran kecamatan Kuta Makmur. Karena sebagian besar biaya sekolah di gratiskan, maka orang tua hanya mengeluarkan biaya untuk membeli kebutuhan sekolah seperti seragam, buku tulis, sepatu, tas dan uang jajan seharihari anaknya.

\section{Pemenuhan Kebutuhan Sosial Budaya}

Menurut Junaidi dalam jurnal "Ibu Rumah Tangga” menyebutkan bahwa seorang istri selain menjadi seorang ibu dan seorang pekerja mereka juga tetap aktif dan harmonis dilingkungannya yang diwujudkan dalam berbagai kegiatan sosial keagamaan seperti: PKK, arisan, majelis taklim dan sebagainya (Junaidi, 2017: 2). Para perempuan di Gampong Keude Krueng juga aktif melaksanakan kegiatan sosial 
keagamaan seperti aktif diacara pengajian, wirit yasinan, menghadiri acara sunatan, walimah takziah dan berbagai kegiatan sosial keagamaan lainnya. Seperti hasil wawancara dengan Ibu Nurmala bahwasanya dengan mereka bekerja sebagai buruh tani mereka sudah bisa mempunyai penghasilan sendiri dan mereka juga sudah bisa memenuhi semua kebutuhan keluarga seperti kebutuhan pangan, sandang, pendidikan anak-anaknya serta biaya sosial budaya dalam masyarakat tanpa meminta lagi kepada suaminya.

\section{Pemenuhan Kebutuhan Kesehatan}

Kesehatan merupakan suatu kebutuhan yang tidak bisa ditinggalkan dari segala kebutuhan yang ada. Hal ini didasarkan karena manusia hidup membutuhkan jasmani dan rohani yang sehat melakukan aktivitasnya. Pemenuhan kebutuhan kesehatan dititik beratkan kepada upaya buruh tani dalam menjaga kesehatan atau menangani masalah kesehatan dengan berobat ke rumah sakit ataupun ke tempat praktik. Namun untuk menghemat biaya para buruh tani biasanya lebih menggunakan cara tradisional untuk berobat seperti meminum perasan jeruk, dikompres, dikerok, dipijit dan lain sebagainya.

\section{Penutup}

Berdasarkan hasil penelitian dan pembahasan di atas secara umum faktor pendorong seorang perempuan untuk bekerja dilatar belakangi oleh masalah ekonomi yang dihadapi dalam kehidupan rumah tangga, faktor pendidikan serta faktor sosial budaya. Peranan istri yang bekerja sebagai buruh tani sangatlah berperan dalam peningkatan ekonomi keluarga, kontribusi pendapatan yang diperoleh oleh para buruh tani perempuan digunakan untuk membantu memenuhi kebutuhan pangan dan sandang, pemenuhan biaya pendidikan anak-anaknya, pemenuhan kebutuhan sosial budaya serta pemenuhan kebutuhan kesehatan keluarganya. Sehingga dapat dikatakan bahwa memang pendapatan yang diperoleh oleh buruh tani perempuan adalah untuk memenuhi ekonomi keluarganya. 


\section{Daftar Pustaka}

Fauzie, Irvan Varis, 2011. Konflik Sosial Dalam Masyarakat : Kebijakan Negara. Online ( http://Vanfauzie.blogspot.com/2011/10/Konflik-Sosial-dlmmasy.html, diakses tanggal 20 Januari 2020).

Femilia septi, at all.2018. Relasi Gender Dan Kehidupan Sosial Ekonomi Dalam Keluarga Buruh Tani Perempuan Di Kecamatan Panti Kabupaten Jember.Jurnal An-Nisa', Vol. 11. No 2.

Junaidi, Heri. 2017. Ibu Rumah Tangga: stereotype perempuan pengangguran. Jurnal Kajian Gender dan anak, Vol 12.No. 01.

Moleong,lexy J. 2014. Metodelogi Penelitian kualitatif. PT Remaja Rosdakarya, Bandung.

Mudzhakat, Anthon. 2006. Wanita Dalam Masyarakat Indonesia, Sunang Kalijga Press,Yogyakarta.

Ngangi, R, Charles. 2016. Modal Sosial Sebagai Srategi Bertahan Hidup Buruh Tani Di Desa Kopiwangker, Kecamatan Langowan Barat, Minahasa. Jurnal AgrSosialEkonomi, Vol 12. No 2A.

Novia, D. 2015. Marginalisasi Perempuan dalam Pembangunan Pertanian.Prosiding Seminar Interdisiplin Ilmu Pendidikan Bagi Anak Perempuan, Pemberdayaan Perempuan dan Perubahan Sosial dan Lingkungan. Program Magister Kajian Perempuan, Program Pasca Sarjana, Universitas Brawijaya, Malang. 